Agro-Science Journal of Tropical Agriculture, Food, Environment and Extension Volume 20 Number 1 (January 2021) pp. 72 - 79

ISSN 1119-7455

\title{
NUTRITIONAL COMPOSITION, MICROBIAL LOAD AND CONSUMER ACCEPTABILITY OF TIGER NUT (Cyperus esculentus), DATE (Phoenix dactylifera L.) AND GINGER (Zingiber officinale Roscoe) BLENDED BEVERAGE
}

\author{
*Ariyo O., Adetutu O. and Keshinro O. \\ Department of Human Nutrition, University of Ibadan, Ibadan, Oyo State, Nigeria \\ "Corresponding author’s email: o.ariyo@ui.edu.ng; ariyoseun@gmail.com
}

\begin{abstract}
Beverage consumption is increasing but rarely used to promote micronutrient intakes in Nigeria. Diversifying the crops in local beverage production could improve dietary diversification and increase nutrients intake. This study determined the nutritional composition, microbial load and consumer acceptability of tiger nut, date and ginger blended beverage. Fresh tiger nuts, date and ginger were processed to formulate four beverage blends in these ratios 100:0:0; 85:10:5; 70:20:10; and 55:30:15. Samples were analysed for proximate, vitamins, minerals, anti-nutrients content and microbiological attributes using standard procedures. Consumer acceptability was determined using a 9-point hedonic scale by 30 untrained panelists. Data were analysed using descriptive statistics, independent t-test and ANOVA at $p \leq 0.05$. Moisture, protein, fat, fibre, ash, carbohydrate (mg $100 \mathrm{~g}^{-1}$ ) and metabolizable energy composition ( $\mathrm{kCal} 100 \mathrm{ml}^{-1}$ ) ranged from 80.33-84.78, 0.71-0.8, 2.96-4.94, 0.20-1.63, 0.34-0.44, 9.10-13.63 and 78.2-101.5, respectively. Thiamin, niacin, ascorbic acid and tocopherol composition $\left(\mathrm{mg} 100 \mathrm{~g}^{-1}\right)$ ranged from 0.30-0.68, 0.08-0.17, 4.73-8.40, and 7.20-15.31, respectively. Calcium, potassium, phosphorus, and iron contents (mg $100 \mathrm{~g}^{-1}$ ) ranged from 1.07-6.79, 164.8-259.3, 43.86-47.1, and 6.88-9.26, respectively. Saponin ranged from 0.01-0.05 mg $100 \mathrm{~g}^{-1}$. Number of colonies were negligible after refrigeration for 10 days. Sensory properties ranged from 6.40-6.63, 4.93-6.40, 4.70-7.20, 5.93-6.90, and 5.27-7.17 for appearance, aroma, taste, consistency and general acceptability, respectively. Date and ginger substitution enhance fibre, ash, carbohydrate, and calcium composition, the shelf life and sensory properties of tiger nut beverage, the blends are generally acceptable to consumers and considered safe up to day 10 when refrigerated.
\end{abstract}

Key words: 'Киппи' sensory properties, antinutrients, nutrient content, microbiological attributes

\section{INTRODUCTION}

Micronutrient malnutrition remains a major public health problem in Nigeria despite availability of large diversity of traditional crops with potentials to contribute to micronutrients intake. Indigenous beverages are prepared from traditional crops like cereals, nuts, fruits and vegetables and are widely consumed by various population age groups as refreshments or part of main meals (Belewu and Abodunrin, 2006) and for nutritional (Corbo et al., 2014) and functional health values (Yilmaz-Akyuz et al., 2019). Many of these beverages are cheap and energy dense but nutrient-poor and therefore limited in contributing to the efforts at promoting good nutrition especially improved micronutrient intake. These shortcomings have prompted efforts at harnessing the potentials of the lesser known and underutilized crops in the development of new products with good sensory acceptance and high nutritional value (Potter and Hotchkins, 1996). Blended non-alcoholic beverage development has been identified as an approach to improve the nutritional quality of traditional products (Jain and
Khurdiya 2004). When blends are selected across two to three food groups, dietary diversity is ensured and this expands the coverage of nutritive, sensory and flavor properties of the beverage.

Tiger nut (Cyperus esculentus L.) is a monocotyledonous plant which belongs to the family Cyperaceae and is made up of over 4000 species (Ekeanyanwu and Ononogbu, 2010). The tubers are about the size of peanuts and are abundantly produced in Nigeria. Tiger nuts are valued as a rich source of starch, dietary fibre, fat, protein and selected minerals like sodium, calcium, potassium and zinc (Oladele and Aina, 2007). In addition, certain functional health properties have been attributed to consumption of tiger nut including treatment and prevention of colon cancer, coronary heart disease, obesity, diabetes, and gastrointestinal disorders, dysentery, diarrhea following high content of soluble glucose (Adejuyitan et al., 2009). The high fiber content makes tiger nut suitable in the management of weight, diabetes and diverticulosis (Beniwal, 2004; Borges et al., 2008). Despite these known benefits,

Please cite as: Ariyo O., Adetutu O. and Keshinro O. (2021). Nutritional composition, microbial load and consumer acceptability of tiger nut (Cyperus esculentus), date (Phoenix dactylifera L.) and ginger (Zingiber officinale Roscoe) blended beverage. Agro-Science, 20 (1), 72-79. DOI: https://dx.doi.org/10.4314/as.v20i1.12 
utilization of tiger nuts in Nigeria is presently limited to consumption as snacks (Ukwuru et al., 2011), drinks (Musa and Hamza, 2013), production of flour to make cakes and biscuits (Chinma et al., 2010 ; 2011), and extraction of oil for cooking (Ezeh et al., 2014). Tiger nut drink commonly called 'Кипnu aya' in Nigeria is relished as a milk substitute and widely consumed throughout the year especially in hot weather of the dry season (Bamishaiye and Bamishaiye, 2011).

Dates (Phoenix dactylifera L.) is known as Dabino in Nigeria. It is a drupe widely used in pudding, bread, cakes, cookies, ice cream, candy bars and cereals and as paste, spread, sweetener, jam, jelly, juice, syrup, vinegar, alcohol and animal feeds especially among Arabs (El Hadrami and AlKhayri, 2012). Dates contain $44-80 \%$ carbohydrates, $0.2-0.5 \%$ fat, $2.3-5.6 \%$ protein and $6-12 \%$ dietary fiber (El-Hadrami and Al-Khayri, 2012) and this makes it an important dietary source of nutrients among its consumers. Dates is also high in phenolic compounds and therefore exhibits antioxidant and antimutagenic properties thereby protecting nucleic acids, proteins and lipids from oxidative damage and carcinogens (Vayalil, 2002). The high phenolic composition also confers antimicrobial properties (El-Hadrami and Al-Khayri, 2012). In addition, date palm fruits are used in Arab countries in the management of aphrodisiacs and treatment of ulcers (Al-Qarawi et al., 2005; Mansouri et al., 2005).

Spices and herbs such as garlic, black cumin ginger (nigella) cloves, cinnamon, thyme, anise and ginger have been used for generations by humans to treat ailments, prevent diseases and as food additives. Ginger (Zingiber officinale) is a plant that has been used as a spice in food preparation and more recently for its antimicrobial and antioxidant properties (Awe et al., 2013). There is an increasing need to diversify sources of dietary nutrients and bioactive compounds, and tweak the food system to promote improved nutrition and health. It has, therefore, become necessary to explore optimization of the potential of existing locally available plant materials to support intakes of micronutrients and other bioactive substances. This is expected to positively impacts on the health and well-being of the local beverage consumers and contribute to making the food system more pro-nutrition. Thus, this study was conducted to formulate and determine the nutritional composition, microbial load and consumer acceptability of tiger nut, date and ginger blended beverage.

\section{MATERIALS AND METHODS \\ Materials}

Fresh tiger nuts, yellow variety (Cyperus esculentus), date palm fruit (Phoenix dactylifera $\mathrm{L}$.), and ginger (Zingiber officinale Roscoe) used for this study were randomly purchased from Bodija market, Ibadan, Nigeria. The samples were prepared at the Dietetics Kitchen, Department of Human Nutrition

and the analysis of the samples was conducted in the Research Laboratory of the Department of Human Nutrition, University of Ibadan and the Central Laboratory of the Institute of Agriculture, Research and Training, Ibadan, Oyo State, Nigeria.

\section{Sample Preparation}

Fresh tubers of tiger nuts, date palm fruit and ginger (peeled) were sorted to remove extraneous materials, bad/cracked nuts and seeds which may affect the taste and keeping quality of the drink. The samples were washed, rinsed with water and used to produce beverage.

\section{Production of Tiger Nut Milk}

Extraction of tiger nut milk was carried out using the method described by Udeozor (2012) with little modification (Figure 1). One kilogram $(1 \mathrm{~kg})$ of the fresh tiger nuts was manually sorted and cleaned to remove extraneous materials. The nuts were soaked in potable water at ratio nut: water (1:3) for $12 \mathrm{~h}$. The soaked nut was milled into a slurry (PhilipsKenwood, UK) with addition of $3 \mathrm{~L}$ of water. The slurry was pressed using muslin cloth $(300 \mu \mathrm{m}$ pore size) to extract the milk. The extracted liquor was homogenized using Q-Link Blender (Model 365XG) and the filtrate obtained was transferred into sterilized plastic bottles, corked and stored in the freezer at $-18^{\circ} \mathrm{C}$ (for not more than three days) prior to analysis.

\section{Production of Date Juice}

The whole of the fruit flesh was obtained by splitting the fruit open to remove the seed. A two-stage extraction described by Agriculture and Consumer Protection was employed with some modifications. The date flesh/water (ratio 4:1) was blended to a fine paste and later centrifuged at $300 \mathrm{rpm}$ (to separate the desirable from undesirable components). At the lower part of the tube, debris was collected and above this layer is a lighter coloured layer and followed by a clear colour liquid which contains the sugar and other soluble solids and the final layer above the clear colour liquid is the thin film of materials which may contain fat (Figure 2).

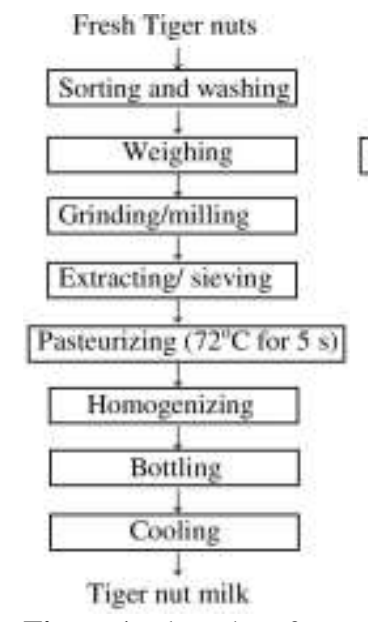

Figure 1: Flow chart for tiger nut milk production Source: Udeozor (2012)

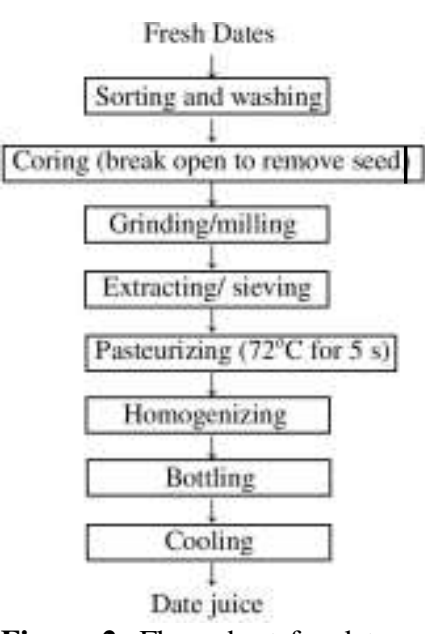

Figure 2: Flow chart for date juice production 


\section{Production of Ginger Juice}

Ginger was peeled and sliced with stainless steel knives and blended/water (1:1) with Q-Link Blender (Model 365XG) for the extraction of juice. The juice was kept for $24 \mathrm{~h}$ in refrigerator $\left(4 \pm 2^{\circ} \mathrm{C}\right)$ for sedimentation. Then the clear juice was siphoned off. The juice was filtered through muslin cloth $(300 \mu \mathrm{m}$ pore size $)$ and the filtrate obtained was transferred into sterilized plastic bottles, corked and stored in the freezer.

\section{Production of Tiger Nut-Date-Ginger \\ Beverage Blend}

Tiger nut milk, date juice and ginger juices were standardized to obtain formulations of varying ratio of 100:0:0 = A, 85:10:5 = B, 70:20:10 = C and 55:30:15 = D. Each blend was homogenized at maximum speed in a Q-Link Blender (Model 356 $\mathrm{XG}$ ) for $10 \mathrm{~min}$. The products were pasteurized at $65^{\circ} \mathrm{C}$ for $30 \mathrm{~min}$. and bottled, then cooled under ambient condition as showed in Figure 3.

\section{Chemical Analysis}

\section{Proximate analysis}

Protein, moisture, fat, ash, and crude fibre content of the samples were analysed as described by the Association of Official Analytical Chemist (AOAC, 2005). All analyses were done in triplicates while carbohydrate content was obtained by difference.

\section{Micronutrient content}

Beta-carotene, vitamins $\mathrm{B}_{1}, \mathrm{~B}_{3}, \mathrm{C}$ and $\mathrm{E}$ were determined using the standard methods of AOAC (2005). Potassium (K), calcium (Ca) and sodium (Na) were analyzed using flame photometry; magnesium $(\mathrm{Mg})$, iron $(\mathrm{Fe})$, manganese $(\mathrm{Mn})$ and copper $(\mathrm{Cu})$ by Atomic Absorption Spectrophotometry, and phosphorus $(\mathrm{P})$ content was determined using spectrophotometric method.

\section{Anti-nutritional factors analysis}

Antinutrients, oxalates, phytates, saponins and tannins were determined as described by AOAC (2005).

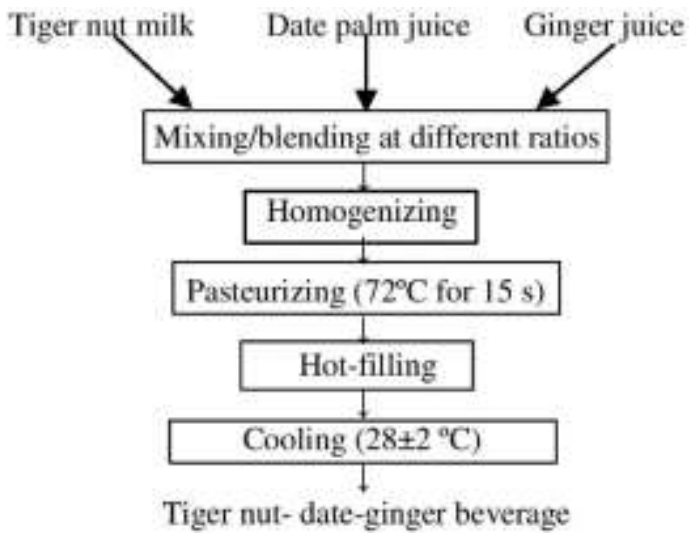

Figure 3: Flow chart for tiger nut- date-ginger beverage production

\section{Microbiological Analysis}

One milliliter $(1 \mathrm{ml})$ of each sample was serially transferred into nine milliliters $(9 \mathrm{ml})$ of the sterile diluent (peptone water) with a sterile pipette and shaken vigorously. Serial dilution was continued until $10^{6}$ dilution was obtained (Cheesbrough, 2006). Aliquot portion $(0.1 \mathrm{ml})$ of the $10^{6}$ and $10^{5}$ dilutions were inoculated onto freshly prepared, surface-dried nutrient agar (NA) and MacConkey agar (MCA) respectively. The same quantity $(0.1 \mathrm{ml})$ of the $10^{4}$ dilution was inoculated onto Potato Dextrose Agar (PDA). The inoculi were spread with a sterile (hockey stick-like) glass spreader to obtain even distribution of isolates after incubation. Nutrient agar and MacConkey agar plates were incubated for $24-48 \mathrm{~h}$ at $37^{\circ} \mathrm{C}$, while PDA plate was incubated at ambient temperature $\left(28 \pm 02^{\circ} \mathrm{C}\right)$ for 3-5 days (Cheesbrough, 2006). Total plate counts for the nutrient and MacConkey Agar were done by counting colonies at the reverse side of the culture plates. Total colony count was expressed in colony forming units per millilitre (cfu ml-1) (Harrigan and McCance, 1990). Plate counts for PDA plates was done using colony counter for the yeasts and hand lens for moulds (Harrigan and McCance, 1990).

\section{Sensory Evaluation}

The sensory analysis was conducted at the Dietetics laboratory of the Department of Human Nutrition, University of Ibadan, Ibadan, Nigeria between 12:00 noon and 3:00 pm. Thirty (30) untrained panelists who were students, and non-smokers evaluated the samples for appearance, aroma, taste, consistency and overall acceptability on a 9-point hedonic scale (like extremely-9, like very much-8, like moderately-7, like slightly-6, neither like nor dislike-5, dislike slightly-4, dislike moderately-3, dislike very much-2, dislike extremely-1) (Iwe, 2010). The order of presentation of samples to the panel was randomized. Bottle water was given to the panelists to rinse their mouths between evaluations.

\section{Statistical Analysis}

Data on three replicates of each parameter from the chemical analysis were analysed using independent T-test and sensory evaluation was analysed using one-way ANOVA. All statistical analyses were conducted using Statistical Package for Social Sciences (SPSS) version 20.0 (SPSS Inc., Chicago, IL USA) at $5 \%$ of significance.

\section{RESULTS AND DISCUSSION Proximate Composition of Tiger Nut, Date and Ginger Bended Beverage}

The proximate composition of the blended beverage samples is presented in Table 1. The moisture content significantly increased with decreasing

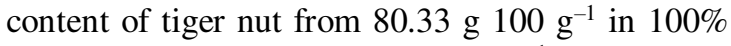
tiger nut beverage to $84.78 \mathrm{~g} 100 \mathrm{~g}^{-1}$ in $55: 30: 15$ tiger nut/date/ginger blend. Quantitatively, the high 


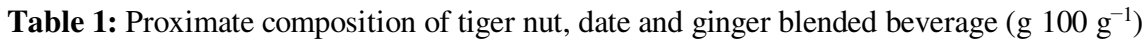

\begin{tabular}{|c|c|c|c|c|}
\hline Parameter & 100:0:0 & $85: 10: 5$ & $70: 20: 10$ & $55: 30: 15$ \\
\hline Moisture & $80.33 \pm 0.01^{\mathrm{a}}$ & $83.7 \pm 0.02^{\mathrm{b}}$ & $84.41 \pm 0.04^{\mathrm{c}}$ & $84.78 \pm 0.04^{\mathrm{d}}$ \\
\hline Crude protein & $0.80 \pm 0.02^{\mathrm{a}}$ & $0.75 \pm 0.02^{\mathrm{b}}$ & $0.72 \pm 0.02^{\mathrm{c}}$ & $0.71 \pm 0.02^{\mathrm{c}}$ \\
\hline Crude fat & $4.94 \pm 0.02^{\mathrm{a}}$ & $4.92 \pm 0.13^{\mathrm{a}}$ & $3.83 \pm 0.02^{\mathrm{b}}$ & $2.96 \pm 0.01^{\mathrm{c}}$ \\
\hline Crude fibre & $0.20 \pm 0.01^{\mathrm{a}}$ & $1.43 \pm 0.00^{\mathrm{b}}$ & $0.78 \pm 0.01^{\mathrm{c}}$ & $1.63 \pm 0.01^{\mathrm{d}}$ \\
\hline Ash & $0.34 \pm 0.01^{\mathrm{a}}$ & $0.39 \pm 0.01^{\mathrm{b}}$ & $0.39 \pm 0.01^{\mathrm{c}}$ & $0.44 \pm 0.01^{\mathrm{d}}$ \\
\hline Carbohydrate & $13.63 \pm 0.01^{\mathrm{a}}$ & $9.10 \pm 0.04^{\mathrm{b}}$ & $10.62 \pm 0.05^{\mathrm{c}}$ & $12.17 \pm 0.01^{\mathrm{d}}$ \\
\hline $\operatorname{ME}\left(\mathrm{kCal} 100 \mathrm{ml}^{-1}\right)$ & $101.51 \pm 1.11^{\mathrm{a}}$ & $84.03 \pm 0.24^{\mathrm{b}}$ & $79.98 \pm 0.30^{\mathrm{c}}$ & $78.20 \pm 0.11^{\mathrm{d}}$ \\
\hline
\end{tabular}

Values with the same superscript on the same row are not significantly different $(p>0.05)$. Values are means of three determinations \pm standard deviation $(n=3) *$ Carbohydrate was obtained by difference ME - metabolizable energy

moisture content reflects a characteristic quality of a typical beverage for thirst quenching and agrees with previously reported range of moisture content in tiger nut milk and chocolate beverage (Akande and Okunola, 2011; Okyere and Odamtten, 2014). This suggests reduced storage quality (shelf life) and increased likelihood of microbial contamination and consequently the safety of the product. High moisture content has been shown to be indicative of poorer shelf life and stability of a product (Akande and Okunola, 2011).

The protein content of the beverage decreased with decreasing composition of tiger nut. Protein

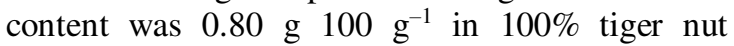
beverage, $0.75 \mathrm{~g} 100 \mathrm{~g}^{-1}$ in $85: 10: 5$ (tiger

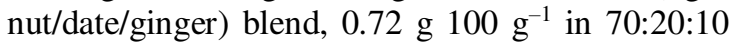

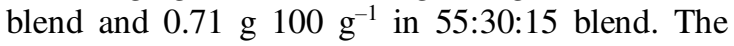
protein content of the blend in this study was low

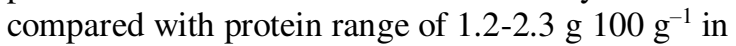
tiger nut beverage (Ukwuru and Ogbodo, 2011) and 2.1-3.4 g $100 \mathrm{~g}^{-1}$ in tiger nut/Vigna-racemosa blend (Folashade et al., 2017). The decreasing protein content could be attributed to reducing tiger nut component, which is the major source of protein in the blends. Though the reduction of the protein composition is not a desirable outcome in this study, the potential to widen sources of other nutrients and health-promoting bioactive substances remain a strong motivation.

The fat content declined with decreasing composition of the tiger nut with highest value in

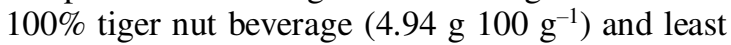

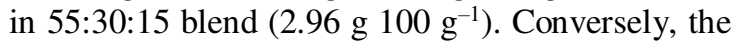
fibre and ash content of the blends increased with decreasing tiger nut composition. The fat content of the beverage was within the range reported by Ukwuru and Ogbodo (2011). Tiger nut is traditionally rich in fat $(25.50 \%)$ (Belewu and Abodunrin, 2006) and the reduction in the value may be attributed to extraction treatments in the course of processing. Fibre composition of the

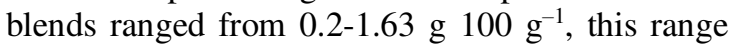
agrees with values reported by Adedokun et al. (2014), but lower than values reported by Musa and Hamza (2013). The increase in the fibre content of the blend suggests the potential of the blend in the prevention and management of weight, diabetes and diverticulosis (Beniwal, 2004; Borges et al., 2008). Fibers also possess the potential to function as prebiotic and thereby promote gut microflora (Singla and Chakkaravarthi, 2017) and enhance nutritional and texturizing properties of beverage (Yilmaz-Akyuz et al., 2019). The ash content of the blends increased with increasing composition of

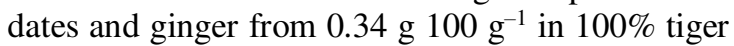

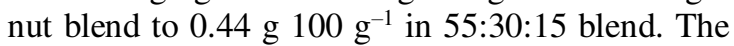
ash content in this study was within the standard limit of $<5 \%(\mathrm{SON})$ as reported by Adedokun et al. (2014), though lower than $1.5 \%$ reported by Ukwuru et al. (2011) and 0.85-0.97 g $100 \mathrm{~g}^{-1}$ in tiger nut/Vigna-racemosa blend (Folashade et al., 2017).

The increasing ash content is a reflection of the improving rheological properties and the nutritional quality of the blends in terms of mineral composition (Schuck et al., 2012).

The carbohydrate content and the metabolizable energy of the blends decreased with increasing

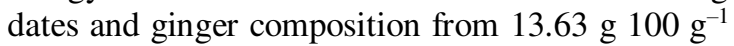
and $101.51 \mathrm{kCal}$ in $100 \%$ tiger nut blend to $12.17 \mathrm{~g}$ $100 \mathrm{~g}^{-1}$ and $78.20 \mathrm{kCal}$ in 55:30:15 blend. Carbohydrate content in the present study is higher than reported by Musa and Hamza (2013), but lower compared to report of Ukwuru and Ogbodo (2011). The variations in the composition could be attributed to the difference in the cultivar of tiger nut and the soil properties which also affect the nutritional composition of the cultivated crops. The decline in the metabolizable energy content of the samples may be attributed to the decline in the carbohydrate and fat content of the blends.

\section{Micronutrient Composition of Tiger Nut, Date and Ginger Blends}

The minerals and vitamins composition of the blends is as shown in Table 2. The calcium (3.26-6.79 mg $\left.100 \mathrm{~g}^{-1}\right)$ and manganese (0.45-0.46 mg $\left.100 \mathrm{~g}^{-1}\right)$ composition increased in blended samples compared to $1.07 \mathrm{mg} / 100 \mathrm{~g}$ and $0.43 \mathrm{mg} 100 \mathrm{~g}^{-1}$ in $100 \%$ tiger nut beverage, respectively. The sodium (1.95-2.66 mg $100 \mathrm{~g}^{-1}$ ), iron (6.88-8.38 mg $100 \mathrm{~g}^{-1}$ ), beta-carotene (21.90-27.67 $\left.\mu \mathrm{g} 100 \mathrm{~g}^{-1}\right)$, ascorbic acid (4.73-7.35 mg $100 \mathrm{~g}^{-1}$ ) and tocopherol content (9.26-12.79 mg $100 \mathrm{~g}^{-1}$ ) increased with increasing tiger nut composition as compared to $4.15 \mathrm{mg} 100 \mathrm{~g}^{-1}$, $9.26 \mathrm{mg} 100 \mathrm{~g}^{-1}, 28.45 \mu \mathrm{g} 100 \mathrm{~g}^{-1}, 8.40 \mathrm{mg} 100 \mathrm{~g}^{-1}$,

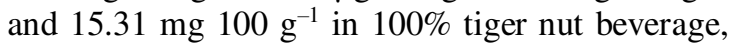
respectively. The increasing calcium level is of public health importance in Nigeria where dietary 
Table 2: Micro-nutrient content of tiger nut, date and ginger blended beverage

\begin{tabular}{|c|c|c|c|c|}
\hline Parameter & 100:0:0 & $85: 10: 5$ & $70: 20: 10$ & $55: 30: 15$ \\
\hline Calcium (mg $100 \mathrm{~g}^{-1}$ ) & $1.07 \pm 0.04^{\mathrm{a}}$ & $3.26 \pm 0.0^{\mathrm{b}}$ & $3.72 \pm 0.03^{\mathrm{c}}$ & $6.79 \pm 0.01^{\mathrm{d}}$ \\
\hline Potassium (mg $\left.100 \mathrm{~g}^{-1}\right)$ & $211.03 \pm 0.78^{\mathrm{a}}$ & $184.98 \pm 0.59^{b}$ & $164.84 \pm 0.30^{\mathrm{c}}$ & $259.27 \pm 0.13^{\mathrm{d}}$ \\
\hline Magnesium (mg $\left.100 \mathrm{~g}^{-1}\right)$ & $6.46 \pm 0.04^{\mathrm{a}}$ & $8.53 \pm 0.04^{b}$ & $4.25 \pm 0.01^{\mathrm{c}}$ & $8.32 \pm 0.04^{\mathrm{d}}$ \\
\hline Sodium (mg $\left.100 \mathrm{~g}^{-1}\right)$ & $4.15 \pm 0.00^{\mathrm{a}}$ & $2.66 \pm 0.06^{\mathrm{b}}$ & $1.97 \pm 0.06^{\mathrm{c}}$ & $1.95 \pm 0.13^{\mathrm{c}}$ \\
\hline Manganese $\left(\mathrm{mg} 100 \mathrm{~g}^{-1}\right)$ & $0.43 \pm 0.04^{\mathrm{a}}$ & $0.45 \pm 0.03^{\mathrm{a}}$ & $0.49 \pm 0.02^{\mathrm{a}}$ & $0.46 \pm 0.02^{\mathrm{a}}$ \\
\hline Phosphorus (mg $100 \mathrm{~g}^{-1}$ ) & $46.54 \pm 0.07^{a}$ & $45.23 \pm 0.25^{\mathrm{b}}$ & $43.86 \pm 0.09^{c}$ & $47.10 \pm 0.23^{\mathrm{d}}$ \\
\hline Iron $\left(\mathrm{mg} 100 \mathrm{~g}^{-1}\right)$ & $9.26 \pm 0.07^{\mathrm{a}}$ & $8.38 \pm 0.04^{\mathrm{b}}$ & $7.26 \pm 0.01^{\mathrm{c}}$ & $6.88 \pm 0.03^{\mathrm{d}}$ \\
\hline Copper $\left(\mathrm{mg} 100 \mathrm{~g}^{-1}\right)$ & $0.03 \pm 0.01^{\mathrm{a}}$ & $0.02 \pm 0.00^{\mathrm{a}}$ & $0.03 \pm 0.00^{\mathrm{a}}$ & $0.03 \pm 0.01^{\mathrm{a}}$ \\
\hline Beta-Carotene $\left(\mu \mathrm{g} 100 \mathrm{~g}^{-1}\right)$ & $28.45 \pm 0.02^{\mathrm{a}}$ & $27.67 \pm 0.02^{\mathrm{b}}$ & $21.90 \pm 0.02^{\mathrm{c}}$ & $23.74 \pm 0.03^{\mathrm{d}}$ \\
\hline Thiamin (mg $\left.100 \mathrm{~g}^{-1}\right)$ & $0.68 \pm 0.01^{\mathrm{a}}$ & $0.58 \pm 0.03^{\mathrm{b}}$ & $0.30 \pm 0.02^{\mathrm{c}}$ & $0.35 \pm 0.02^{d}$ \\
\hline $\operatorname{Niacin}\left(\mathrm{mg} 100 \mathrm{~g}^{-1}\right)$ & $0.17 \pm 0.01^{\mathrm{a}}$ & $0.14 \pm 0.01^{\mathrm{b}}$ & $0.08 \pm 0.01^{\mathrm{c}}$ & $0.10 \pm 0.01^{\mathrm{d}}$ \\
\hline Ascorbic Acid $\left(\mathrm{mg} 100 \mathrm{~g}^{-1}\right)$ & $8.40 \pm 0.14^{\mathrm{a}}$ & $7.35 \pm 0.14^{\mathrm{b}}$ & $4.75 \pm 0.17^{\mathrm{c}}$ & $4.73 \pm 0.21^{\mathrm{c}}$ \\
\hline Tocopherol $\left(\mathrm{mg} 100 \mathrm{~g}^{-1}\right)$ & $15.31 \pm 0.03^{\mathrm{a}}$ & $12.79 \pm 0.03^{\mathrm{b}}$ & $7.20 \pm 0.02^{\mathrm{c}}$ & $9.26 \pm 0.02^{\mathrm{d}}$ \\
\hline
\end{tabular}

Values with the same superscript on the same row are not significantly different $(p>0.05)$.

Values are means of three determinations \pm standard deviation $(n=3)$

intake of calcium is largely inadequate and dairy intake is limited due to high cost. The calcium content in the blends is similar to $2.8-6.3 \mathrm{mg} 100 \mathrm{~g}^{-1}$ found in Vigna-racemosa fortified tiger nut beverage (Folashade et al., 2017) and 5.44-7.35 mg $100 \mathrm{~g}^{-1}$ in calcium-fortified tiger nut beverage (Abulude et al., 2006). Adequate intake of calcium is good for bone health (Sale and Elliott-Sale, 2019) and regulation of blood cholesterol level and blood pressure (Rautiainen et al., 2013). The declining iron content with increasing composition of dates and ginger is an undesirable outcome. Iron deficiency anaemia is still a public health nutrition problem globally with consequences on human health, social and economic development of nations (WHO/UNICEF, 2001). In Africa, iron deficiency affects about twenty percent of women of reproductive age and pregnant women (Harika et al., 2017). Consequences of anaemia include lower attentiveness, poor school performance, poor learning retention for children and adolescents, reduced work performance and risk of psychiatric disorders for adults (WHO/UNICEF, 2001) and poor pregnancy outcomes such as low birth weight, infant and maternal mortality (Scholl and Hediger, 1994).

The importance of vitamins in maintaining good health cannot be over-emphasized. Beta carotene, thiamin, niacin, ascorbic acid and tocopherol content of the blends reduced with increasing composition of dates and ginger. This confirms that tiger nut is the best source of these vitamins in the basal ingredients for the blends. Beta carotene, ascorbic acid and tocopherols are antioxidants with distinct roles in promoting cell integrity and prevention of cancer (Onyechi et al., 2012). The findings in this study suggest the need to incorporate some crops that are good sources of dietary antioxidants vitamins in the formulation.

Anti-Nutrient Composition and Microbial Load of Tiger Nut, Date and Ginger Blended Beverage The anti-nutrient composition of the beverage blends is presented in Table 3 . There is a decline in the saponin, phytate and oxalate contents with substitution of tiger nut; this suggests increase bioavailability of nutrients in these blends. Antinutrients reduce the bio-availability of nutrients by forming a complex with nutrients thereby limiting their absorption. Phytates for example decrease the bioavailability of calcium, magnesium, iron and phosphorus (Anuonye et al., 2012). Tannins are water soluble polyphenols found in the seed coats of many foods (Onwuka, 2005) and could leach out during soaking and hinder nutrients bioavailability, however, tannin is not detectable in tigernut beverage blends. High levels of phytates in human nutrition are toxic and limits the bioavailability of calcium, magnesium, iron and phosphorus by the formation of insoluble compounds with the minerals (Aletor and Omodara, 1994). The microbial load of tiger nut, date and ginger blended beverage ( $\mathrm{cfu} \mathrm{ml}^{-1}$ ) in ambient and refrigerated storage condition is shown (Table 4). The numbers of microorganisms present both in ambient and refrigerated conditions increased with duration of storage. All ambientstored samples had high numbers of micro-flora in them. Highest bacteria load $\left(26.0 \times 10^{-1} \mathrm{cfu} \mathrm{ml}^{-1}\right)$ occurred in $100 \%$ tiger nut blend and lowest microbial load $\left(4.0 \times 10^{-1} \mathrm{cfu} \mathrm{ml}^{-1}\right)$ in 55:30:15 blend. This suggests that the tiger nut, dates and ginger blends possibly benefitted from the high phenolic composition of dates and consequently enhanced antimicrobial properties (El-Hadrami and Al-Khayri, 2012) and the inhibitory effect of spices (ginger juice) towards micro-organisms.

The microbial count is not surprising following the high moisture content of the blend and also suggests that inclusion of dates and ginger improves its safety for consumption. Badau (2007) reported that addition of black pepper (Piper guineense) and hot pepper (Capsicum frutescens) did not affect the microbial count of tiger nut milk. In this study, total bacteria count reduced with increasing dates and ginger composition for storage

Table 3: Anti-nutrient composition of tiger nut, date and ginger blended beverage $\left({\left.\mathrm{g} 100 \mathrm{~g}^{-1}\right)}^{2}\right.$

\begin{tabular}{lllll}
\hline Parameter & $100: 0: 0$ & $85: 10: 5$ & $70: 20: 10$ & $55: 30: 15$ \\
\hline Saponin & $0.05 \pm 0.00^{\mathrm{a}}$ & $0.04 \pm 0.00^{\mathrm{b}}$ & $0.01 \pm 0.00^{\mathrm{c}}$ & $0.02 \pm 0.00^{\mathrm{d}}$ \\
Phytate & $0.01 \pm 0.00^{\mathrm{a}}$ & $0.01 \pm 0.00^{\mathrm{b}}$ & $0.00 \pm 0.00^{\mathrm{b}}$ & $0.00 \pm 0.00^{\mathrm{d}}$ \\
Oxalate & $0.01 \pm 0.00^{\mathrm{a}}$ & $0.00 \pm 0.00^{\mathrm{b}}$ & $0.00 \pm 0.00^{\mathrm{b}}$ & $0.00 \pm 0.00^{\mathrm{b}}$ \\
Tannin & $0.00 \pm 0.00^{\mathrm{a}}$ & $0.00 \pm 0.00^{\mathrm{a}}$ & $0.00 \pm 0.00^{\mathrm{a}}$ & $0.00 \pm 0.00^{\mathrm{a}}$ \\
\hline Values with the same superscript on the same row are not \\
significantly different $(p>0.05)$. Values are means of three \\
determinations \pm standard deviation $(n=3)$
\end{tabular}


Table 4: Microbial load of tiger nut, date and ginger blended beverage $\left(\mathrm{cfu} \mathrm{ml}^{-1}\right)$ in ambient and refrigerated storage condition

\begin{tabular}{|c|c|c|c|c|c|c|c|}
\hline \multirow[b]{2}{*}{ Samples } & & \multicolumn{2}{|c|}{$5^{\text {th }}$ day } & \multicolumn{2}{|c|}{$10^{\text {th }}$ day } & \multicolumn{2}{|c|}{$15^{\text {th }}$ day } \\
\hline & & Amb. & Ref. & Amb. & Ref. & Amb. & Ref. \\
\hline \multirow[t]{3}{*}{ 100:0:0 } & $\mathrm{TBC}$ & $26.0 \pm 0.01^{\mathrm{a}}$ & $13.0 \pm 0.00^{\mathrm{a}}$ & $33.0 \pm 0.01^{\mathrm{b}}$ & $14.0 \pm 0.00^{\mathrm{b}}$ & $36.0 \pm 0.01^{\mathrm{c}}$ & $14.0 \pm 0.00^{\mathrm{b}}$ \\
\hline & TYC & $4.0 \pm 0.00^{\mathrm{a}}$ & $2.0 \pm 0.01^{\mathrm{a}}$ & $9.0 \pm 0.02^{\mathrm{b}}$ & $3.0 \pm 0.01^{\mathrm{b}}$ & $16.0 \pm 0.00^{\mathrm{c}}$ & $8.0 \pm 0.00^{\mathrm{c}}$ \\
\hline & TCC & $\mathrm{NC}$ & $\mathrm{NC}$ & $\mathrm{NC}$ & $\mathrm{NC}$ & $19.0 \times 10^{-1}$ & $\mathrm{NC}$ \\
\hline \multirow[t]{3}{*}{$85: 10: 5$} & $\mathrm{TBC}$ & $22.0 \pm 0.01^{\mathrm{a}}$ & $10.0 \pm 0.00^{\mathrm{a}}$ & $26.0 \pm 0.00^{\mathrm{b}}$ & $13.0 \pm 0.01^{\mathrm{b}}$ & $28.0 \pm 0.01^{\mathrm{c}}$ & $11.0 \pm 0.00^{\mathrm{c}}$ \\
\hline & TYC & $4.0 \pm 0.00^{\mathrm{a}}$ & $0.00 \pm 0.00^{\mathrm{a}}$ & $8.0 \pm 0.00^{\mathrm{b}}$ & $1.0 \pm 0.01^{\mathrm{b}}$ & $13.0 \pm 0.01^{\mathrm{c}}$ & $4.0 \pm 0.01^{\mathrm{c}}$ \\
\hline & TCC & $\mathrm{NC}$ & $\mathrm{NC}$ & $\mathrm{NC}$ & $\mathrm{NC}$ & $8.0 \times 10^{-1}$ & $\mathrm{NC}$ \\
\hline \multirow[t]{3}{*}{$70: 20: 10$} & $\mathrm{TBC}$ & $16.0 \pm 0.00^{\mathrm{a}}$ & $9.0 \pm 0.00^{\mathrm{a}}$ & $20.0 \pm 0.01^{\mathrm{b}}$ & $8.0 \pm 0.01^{\mathrm{b}}$ & $23.0 \pm 0.01^{\mathrm{c}}$ & $9.0 \pm 0.00^{\mathrm{a}}$ \\
\hline & TYC & $3.0 \pm 0.01^{\mathrm{a}}$ & $0.0 \pm 0.00^{\mathrm{a}}$ & $8.0 \pm 0.00^{\mathrm{b}}$ & $2.0 \pm 0.01^{\mathrm{b}}$ & $14.0 \pm 0.00^{\mathrm{c}}$ & $5.0 \pm 0.00^{\mathrm{c}}$ \\
\hline & TCC & $\mathrm{NC}$ & $\mathrm{NC}$ & $\mathrm{NC}$ & $\mathrm{NC}$ & $13.0 \times 10^{-1}$ & $\mathrm{NC}$ \\
\hline \multirow[t]{3}{*}{$55: 30: 15$} & TBC & $13.0 \pm 0.02^{\mathrm{a}}$ & $6.0 \pm 0.01^{\mathrm{a}}$ & $19.0 \pm 0.01^{\mathrm{b}}$ & $5.0 \pm 0.01^{\mathrm{b}}$ & $22.0 \pm 0.01^{\mathrm{c}}$ & $6.0 \pm 0.01^{\mathrm{a}}$ \\
\hline & TYC & $4.0 \pm 0.00^{\mathrm{a}}$ & $1.0 \pm 0.01^{\mathrm{a}}$ & $5.0 \pm 0.02^{\mathrm{b}}$ & $4.0 \pm 0.01^{\mathrm{b}}$ & $11.0 \pm 0.01^{\mathrm{c}}$ & $9.0 \pm 0.01^{\mathrm{c}}$ \\
\hline & TCC & $\mathrm{NC}$ & $\mathrm{NC}$ & $\mathrm{NC}$ & $\mathrm{NC}$ & $8.0 \times 10^{-1}$ & $\mathrm{NC}$ \\
\hline
\end{tabular}

Values with the same superscript on the same row are not significantly different $(p>0.05)$.

Values are means $\times 10^{-1}$ of two determinations \pm standard deviation $(n=2)$. TBC - total bacteria count; TYC - total yeast count;

TCC - total coliform count; NC - no coliform; Amb. - ambient temperature; Ref. - refrigerated

up to 10 days, this shows that dates and ginger combination may be useful in improving the shelf life of tiger nut milk. Ajayi and Oyetayo (2009) reported that moisture content encouraged growth of microorganisms and food spoilage. In this study, the rate of spoilage is faster at ambient temperature and the shelf life of products is limited. Refrigeration reduced the growth of bacteria and yeast and prevented the growth of coli forms up to day 15 of storage. The lower the temperature, the slower the chemical reactions, enzyme actions and microbial growth (Essuman, 1990). This suggests the need to ensure safe environment for the preparation, storage and vending of tiger nut, dates and ginger blends. The increasing practice of tiger nut beverage vending therefore needs to be regulated and minimum benchmark must be created for the vendors including availability of a cooling devices for safe keeping of the beverage.

\section{Sensory Properties of Tiger Nut, Date and Ginger Blends}

The sensory properties of the blends are as indicated in Table 5. There was no significant difference in the appearance of the blends with highest being 6.63 in 85:10:5 blend and lowest (6.40) in 55:30:15 blend. The aroma of the blend increased from 4.93 in $100 \%$ tiger nut blend to 6.40 in 55:30:15 blend. Taste also improves with increasing substitution from 4.70 in $100 \%$ tiger nut blend to 7.20 in 55:30:15 blend. Similar improvement was observed for consistency and general acceptability from 5.93 to 6.90 and 5.27 to 7.17 , respectively.

The improving sensory properties with increasing tiger nut substitution level shows likelihood of acceptability of the blend by the tiger nut beverage consumers. The general acceptability of the blends is promising for commercialization of the blends and conforms with reports on orange-tiger nut beverage (Ukwuru et al., 2011). Increasing taste could be attributed to the sweetening properties of date palm fruits (El Hadrami and Al-Khayri, 2012) and higher aroma and general acceptability could be a result of satiety and flavor associated with ginger (Mansour et al., 2012).
Table 5: Sensory evaluation analysis of tiger nut, date and ginger blended beverage

\begin{tabular}{lllll}
\hline Parameter & $100: 0: 0$ & $85: 10: 5$ & $70: 20: 10$ & $55: 30: 15$ \\
\hline $\begin{array}{l}\text { Appear- } \\
\text { ance }\end{array}$ & $6.57 \pm 1.36^{\mathrm{a}}$ & $6.63 \pm 1.10^{\mathrm{a}}$ & $6.50 \pm 1.28^{\mathrm{a}}$ & $6.40 \pm 1.71^{\mathrm{a}}$ \\
Aroma & $4.93 \pm 1.89^{\mathrm{a}}$ & $6.37 \pm 1.45^{\mathrm{b}}$ & $6.40 \pm 1.38^{\mathrm{b}}$ & $6.40 \pm 1.54^{\mathrm{b}}$ \\
Taste & $4.70 \pm 2.35^{\mathrm{a}}$ & $6.87 \pm 1.33^{\mathrm{b}}$ & $6.97 \pm 1.40^{\mathrm{b}}$ & $7.20 \pm 1.49^{\mathrm{b}}$ \\
$\begin{array}{l}\text { Consist- } \\
\text { ency }\end{array}$ & $5.93 \pm 1.80^{\mathrm{a}}$ & $6.60 \pm 1.39^{\mathrm{b}}$ & $6.70 \pm 1.10^{\mathrm{ab}}$ & $6.90 \pm 1.49^{\mathrm{b}}$ \\
$\begin{array}{l}\text { General } \\
\text { Acceptability }\end{array}$ & $5.27 \pm 1.93^{\mathrm{a}}$ & $6.67 \pm 1.30^{\mathrm{b}}$ & $6.70 \pm 1.74^{\mathrm{b}}$ & $7.17 \pm 1.26^{\mathrm{b}}$ \\
$\begin{array}{l}\text { Values with the same superscript on the same role are not } \\
\text { significantly different }(p>0.05) . \text { Values are means of thirty } \\
\text { determinations } \pm \text { standard deviation }(n=30)\end{array}$
\end{tabular}

\section{CONCLUSION}

Date and ginger substitution enhance fibre, ash, carbohydrate, calcium, and manganese composition, and sensory properties of tiger nut beverage; and inhibit bacteria and yeast growth. Tiger nut, date and ginger blends are generally acceptable to consumers and considered safe up to day 10 when refrigerated. The 55:30:15 blend of tiger nut, dates and ginger is hereby recommended for consumption following higher calcium, potassium, beta-carotene, and tocopherol content and higher sensory acceptability. The iron and protein content of the blends reduce with increasing substitution; hence the inclusion of iron- and protein rich crops is recommended for subsequent formulations. This approach has the potential to increase the micronutrient intakes and strengthen the food system to promote adequate nutrition.

\section{ACKNOWLEDGEMENT}

The authors are grateful to the panelists and the laboratory staff that did the analyses. We thank also the Department of Human Nutrition, University of Ibadan for continued support and protected time given for the use of the Dietetic Kitchen and the Laboratory during this study.

\section{Authors' Contributions}

All the authors participated in the conceptualization of the study, Ariyo and Adetutu developed the methodology. Keshinro and Ariyo validated the methodology. Adetutu conducted the sample selection, preparation and analysis under the supervision of Ariyo. Keshinro and Ariyo supervised the entire activities. Adetutu prepared the first draft, Ariyo reviewed and edited. Final manuscript was read and approved by Keshinro. 


\section{REFERENCES}

Abulude F.O., Ogunkoya M.O. and Oni V.A. (2006). Mineral composition, shelf life and sensory attributes of fortified 'kunuzaki' beverage. Acta Sci. Pol. Technol. Aliment, 5 (1), 155-162

Adedokun I.I., Okorie S.U., Onyeneke E.N. and Anoruo S.A. (2013): Evaluation of yield, sensory and chemical characteristics of soft unripened cheese produced with partial incorporation of bambara nut milk. Acad. J. Food Res., 1 (1), 014-018

Adejuyitan J.A., Otunola E.T., Akande E.A., Bolarinwa I.F. and Oladokun F.M. (2009). Some physicochemical properties of flour obtained from fermentation of tiger nut (Cyperus esculentus). Afr. J. Food Sci., 3, 51-55

Ajayi O.B. and Oyetayo F.L. (2009). Potentials of Kerstingiella geocarpa as health food. J. Med. Food, 12, 184-187

Akande E.A. and Okunola D.D. (2011). Production and quality evaluation of wild pepper (Erythrococoa anomala) flavoured chocolate drinks. J. Agric. Sc. and Tech., A1, 672-677

Aletor V.A. and Omodara O.A. (1994). Studies of some leguminous brow plants with particular reference to their proximate, mineral and some endogenous antinutritional constituents. Anim. Feed Sci. Technol., 46, 343-348

Al-Qarawi A.A., Abdel-Rahman H., Ali B.H., Mousa H.M. and El-Mougy S.A. (2005). The ameliorative effect of dates (Phoenix dactylifera L.) on ethanolinduced gastric ulcer in rats. J. Ethnopharmacol., 98 (3), 313-317

Anuonye J.C., Jigam A.A. and Ndaceko G.M. (2012). Effects of extrusion-cooking on the nutrient and antinutrient composition of pigeon pea and unripe plantain blends. J. Appl. Pharm. Sci., 2 (5), 158-162

AOAC (2005). The Official Method of Analysis (17th ed.), Association of Official Analytical Chemists, Washington D.C. USA.2005.08

Awe F.B., Fagbemi T.N., Ifesan B.O.T., and Badejo A.A. (2013). Antioxidant properties of cold and hot water extracts of cocoa, hibiscus flower extract, and ginger beverage blends. Food Res. Int., 52, 490-495

Badau M.H. (2007). Sensory and microbial evaluation of pearl millet kunun zaki saccharified with malt from some pearl millet and sorghum cultivators. AgroScience, 6 (1), 116-127

Bamishaiye E.I. and Bamishaiye O.M. (2011). Tiger nut: as a plant, its derivatives and benefits. African J. Food, Agric. Nutr. Dev., 11 (5), 5157-5170

Belewu M.A. and Abodunrin O.A. (2006). Preparation of Kunnu from unexploited rich food source: Tiger nut (Cyperus esculentus). World J. Dairy Food Sci., 1, 19-21

Beniwal R.S. (2004). A randomised trial of yoghurt for prevention of antibiotic-associated diarrhoea. Digestive Dis. Sci., 48, 2077-2082

Chinma C.E., Abu J.O. and Abubakar Y.A. (2010). Effect of tiger nut (Cyperus esculentus) flour addition on the quality of wheat-based cake. Int. J. Food Sci. Technol., 45 (8), 1746-1752

Chinma C.E., James S., Imam H., Ocheme O.B., Anuonye J.C. and Yakubu C.M. (2011). Physicochemical and sensory properties, and in-vitro digestibility of biscuits made from blends of tiger nut (Cyperus esculentus) and pigeon pea (Cajanus cajan). Niger. J. Nutr. Sci., 32 (1), 55-62
Folashade B.I., Akinwumi A.J., Samson O.A. and Akinwunmi A.O. (2017). Nutritional composition and sensory attributes of "kunnu-aya" fortified with Vigna-racemosa flour. SDRP J. Food Sci. Technol., 2, 1-6

Borges O., Gonçalves B., Sgeoeiro L., Correia P. and Silva A. (2008). Nutritional quality of chestnut cultivars from Portugal. Food Chem., 106, 976-984

Cheesbrough M. (2006). District Laboratory Practice in Tropical Countries, Part 2. Low price edition. Cambridge University Press, London. pp. 74-79

Corbo M.R., Bevilacqua A., Petruzzi L., Casanova F.P. and Sinigaglia M. (2014). Functional beverages: the emerging side of functional foods. Compr. Rev. Food Sci. Food Saf., 13, 1192-1206

Ekeanyanwu R.C. and Ononogbu C.I. (2010). Nutritive value of Nigerian tiger nut (Cyperus esculentus L.) Agric. J., 5 (5), 297-300

El-Hadrami A. and Al-Khayri J.M. (2012). Socioeconomic and traditional importance of date palm. Emirates $J$. Food Agric., 24, 371-385

Ezeh O., Gordon M.H. and Niranjan K. (2014). Tiger nut oil (Cyperus esculentus L.): A review of its composition and physico-chemical properties. Eur. J. Lipid Sci. Technol., 116 (7), 783-794

Harika R., Faber M., Samuel F., Kimiywe J., Mulugeta A. and Eilander A. (2017). Micronutrient status and dietary intake of iron, vitamin A, iodine, folate and zinc in women of reproductive age and pregnant women in Ethiopia, Kenya, Nigeria and South Africa: a systematic review of data from 2005 to 2015. Nutrients, 9 (10), 1096

Harrigan W.F. and McCance M.E. (1990). Laboratory Methods in Food and Diary Microbiology. $\quad 8^{\text {th }}$ ed. London: Academic Press Inc. pp. 286-303

Iwe M.O. (2010). Handbook of sensory methods and analysis. Rojoint communication services Ltd., Enugu. pp. 75-78

Jain S.K. and Khurdiya D.S. (2004). Vitamin C enrichment of fruit juice based ready-to-serve beverages through blending of Indian gooseberry (Emblica officinalis Gaertn.) juice. Plant Foods Hum. Nutr., 59 (2), 63-66

Essuman K.M. (1990). Local packaging of foods in Ghana. Food Nutr. Bull., 12 (1), 1-5

Mansour M.S., Ni Y.M., Roberts A.L., Kelleman M., RoyChoudhury A. and St-Onge, M.P. (2012). Ginger consumption enhances the thermic effect of food and promotes feelings of satiety without affecting metabolic and hormonal parameters in overweight men: a pilot study. Metabolism, 61 (10), 1347-1352

Mansouri A., Embarek G., Kokkalou E. and Kefalas P. (2005). Phenolic profile and antioxidant activities of the Algerian ripe date palm fruit (Phoenix dactylifera), Food Chem., 89, 411-420

Musa A.A. and Hamza A. (2013). Comparative analysis of locally prepared 'kunun aya' (tiger nut milk) consumed by students of Kaduna State University, Kaduna, Nigeria. Sci. World J., 8 (2), 13-18

Okyere A.A. and Odamtten G.T. (2014). Physicochemical, functional and sensory attributes of milk prepared from irradiated tiger nut (Cyperus esculentus L.). J. Radiat. Res. Appl. Sci., 7 (4), 583-588

Oladele A.K. and Aina J.O. (2007). Chemical composition and functional properties of flour produced from two varieties of tiger nut (Cyperus esculentus). Afr. J. Biotechnol., 6, 2473-2476 
Onwuka G.I. (2005). Food Analysis and Instrumentation: Theory and Practice. Napthli Printers, Nigeria. p.198

Onyechi A.U., Ibeanu V.N., Eme P.E. and Kelechi M. (2012). Nutrient, phytochemical composition and sensory evaluation of soursop (Annona muricata) pulp and drink in Southern Eastern Nigeria. Int. J. Basic Appl. Sci., 12 (6), 53-57

Potter N.N. and Hotchkins J.H. (1996) Food Science. C.B.S Publishers, New York, pp. 235-432

Rautiainen S., Wang L., Manson J.E. and Sesso H.D. (2013). The role of calcium in the prevention of cardiovascular disease - a review of observational studies and randomized clinical trials. Curr. Atheroscler. Rep., 15 (11), 362-364

Sale C. and Elliott-Sale K.J. (2019). Nutrition and athlete bone health. Sports Med., 1-13

Scholl T.O. and Hediger M.L. (1994). Anemia and irondeficiency anemia: compilation of data on pregnancy outcome. Am. J. Clin. Nutr., 59 (2), 492S-501S

Schuck P., Dolivet A. and Jeantet R. (2012). Analytical methods for food and dairy powders. West Sussex: Wiley, p. 153

Singla V. and Chakkaravarthi S. (2017). Applications of prebiotics in food industry: A review. Food Sci. Technol. Int., 23 (8), 649-667
Udeozor L.O. (2012). Tiger nut-soy milk drink: preparation, proximate composition and sensory qualities. Int. J. Food and Nutr. Sci., 1 (4), 18-26

Ukwuru M.U., Ibeneme C.L. and Agbo G.I. (2011). New product development from tiger nut (Cyperus esculentus) and their sensory, proximate and microbiological evaluation. Pak. J. Nutr., 10 (2), 101-105

Ukwuru M.U. and Ogbodo A.C. (2011). Effect of processing treatment on the quality of tiger nut milk. Pak. J. Nutr., 10 (1), 95-100

Vayalil P.K. (2002). Antioxidant and antimutagenic properties of aqueous extract of date fruit (Phoenix dactylifera L. Arecaceae). J. Agric. Food Chem., 50 (3), 610-617

WHO/UNICEF (2001). World Health Organization (WHO)/United Nations International Children's Fund (UNICEF). Iron Deficiency Anaemia: Assessment, Prevention, and Control: A Guide for Programme Managers; World Health Organization: Geneva, Switzerland, p. 33

Yilmaz-Akyuz E., Ustun-Aytekin O., Bayram B. and Tutar Y. (2019). Nutrients, bioactive compounds, and health benefits of functional and medicinal beverages. In: Nutrients in Beverages (pp. 175-235) Academic Press 